\title{
The Effect of Preventive Guideline Program about Genital Tract Infection on Adolescent Female's Knowledge and Practice at Assuit City
}

\author{
Hameida Alam Eldien, Assistant Professor \\ Maternity Health Nursing, Faculty of Nursing, Assuit University \\ Howieda Fouly, Lecturer \\ Maternity Health Nursing, Faculty of Nursing, Assuit University
}

Salwa A. Marzouk, Assistant Professor

Pediatric Nursing, Faculty of Nursing, Assuit University

Youssria El-sayed, Assistant Professor

Pediatric Nursing, Faculty of Nursing, Sohag University

Neama Mohamed El magrabi, Assistant Professor
Community Health Nursing, Faculty of Nursing, Assuit University

\begin{abstract}
Good health behavior safeguards the health of adolescent females by reducing their vulnerability to reproductive tract infections. Objective: Assess the adolescent female students' knowledge and practice regarding prevention of genital tract infection, and assess the effectiveness of the program on students' knowledge and practice regarding prevention of genital tract infection. Setting: This study conducted in randomly three secondary schools that represent the different districts of Assiut city in Egypt. Subjects: A total of 124 secondary female's students were selected. Tools: A structured interview schedule was designed to assess socio-demographic data and students' health knowledge and practices at pre- and post-intervention. Results: The mean age of participants' students was $16.7 \pm 1.2$ years. The study revealed an improvement of knowledge regarding personal health practice toward genital tract hygiene among adolescents. Also the students reported significant improvements in the perineal hygiene practices. There was a positive correlation between students' knowledge and their practices. Conclusion: The post-intervention assessment revealed an obvious improvement of knowledge and practice among the studied students. Recommendations: Appropriate educational strategies as simple illustration, brochures and booklets should be available for students to increase their awareness about the healthy practices regarding genital tract and use reproductive health service.
\end{abstract}

Keywords: Health behaviors; Female adolescent; Genital tract infection; Preventive guideline program.

\section{Introduction}

Female genital tract infection is one of the major public health problems and consider as a 'silent' epidemic. Furthermore, females with self-reported symptoms of reproductive morbidity do not seek treatment due to "taboos" and embarrassments regarding reproductive health. The untreated infections can lead to health and social consequences, in addition to female emotional distress related to gynecological morbidity ${ }^{(1)}$.
The physiological risk of increased susceptibility to infections among adolescent girls is due to anatomical factors; the cervix of adolescent females is not sufficiently developed and the presence of greater cervical ectopy which makes the cervix more susceptible to gonorrhea, chlamydia and Human Papilloma Virus (HPV). Also, a lot of interrelated and complex factors that put adolescents at risk of STI include poor education, unemployment and poverty ${ }^{(2)}$. 
Niekerk et al. ${ }^{(3)}$ confirmed that female's adolescents are susceptible for unhealthy behavior that could affect their health and wellbeing. This is due to influence of cultures' diversity among their age group, in addition to distinctive peer pressure effect during this stage. Therefore, inaccurate and inadequate concepts regarding health, lifestyle, and physical activity and fitness could be formulated among adolescents. According to Omidvar $\&$ Begum $^{4}$, there are clear links between health behavior such as poor menstrual hygiene and Urinary and Reproductive Tract Infections.

Adolescents' female at risk, must change their hygienic practices and behaviors via prevention and avoidance of genital tract infection which is the most effective way of reducing the adverse consequences $^{(5)}$. These preventive measures may include; improving knowledge of reproductive physiology, improving personal hygiene, nutrition, and providing an appropriate help through improving health services, and changing practices regarding genital tract infection ${ }^{(6)}$.

Nurses working in health settings should focus on providing female students in different ages specially adolescence stage with comprehensive information about genital tract infection. Thus, adolescent females need to be given evidences, for genital tract infection, transition ways, and symptoms. In addition to the consequences of genital tract infection and how to prevent it, through change behaviors and focus on secure advice about examples of appropriate behaviors $^{(7)}$.

\section{Significance of the study:}

In Egypt, adolescents represent onefifth (21\%) of the total population. ${ }^{8}$ Therefore, this critical age has many medical problems, most common is genital tract infection due to lack of knowledge among adolescent females which may lead to several genitourinary diseases ${ }^{(9)}$. Also, absence of reproductive health education through the formal schools' education curriculum in Egypt $^{(10)}$ and the existing service delivery system is not catering to the needs of adolescents, especially unmarried $^{(11)}$. In addition, inadequate programmed efforts from both public and private sectors is a significant obstacle to meet the growing unmet needs for adolescents' knowledge. Therefore, it is very interesting to carry out this study for improving the accessibility of adolescents to preventive and curative services including information and counseling.

\section{Aim of the Study}

This study aimed to:

1- Assess the adolescent female students' knowledge and practice regarding prevention of genital tract infection.

2- Assess the effectiveness of the program on students' knowledge and practice regarding prevention of genital tract infection.

\section{Research Hypotheses:}

The following hypotheses were expected:

- Adolescents female students attainted the program be higher knowledge regarding prevention of genital tract infection than before they attainted.

- The levels of the practices among female's adolescents regarding prevention of genital tract infection at post program are higher than those pre-program.

- There is a association between students' knowledge and practice regarding genital tract infection?

\section{Materials and Method}

\section{Materials}

Design: A quasi-experimental design was utilized to conduct this study.

Setting: The study was carried out in three locations: Assiut female secondary school, Taha Hanafey secondary school and nursing secondary school. These schools 
represented three different districts of Assiut city in Egypt.

Subjects: The students were selected using the multistage sampling technique: A list of all female secondary schools within the four districts (south, north, east \& west) of Assiut city was done. Then each school was randomly given a sequential number such as $(1,2,3 \ldots n)$. Next, these numbers were written to represent each school in a piece of paper that was fold and put in a jar and shacked well then a piece by piece of the folded papers packed up. This way resulted in the selection of three different schools, two public secondary schools and one nursing secondary school. The same way was followed to pick-up participated classes in the study where each grade had 3 classes. The sample recruited from October to December 2015.

Sample size: A total of 124 female students from the three secondary schools were included in the study sample under the following inclusion criteria:

1) Female students of secondary schools from $1^{\text {st }}, 2^{\text {nd }}$ and $3^{\text {rd }}$ grades.

2) Age range between 15-19 years. Sample size was dependent on the average number of students of each school which ranged from 200-300 students.

Tools: Two tools were used in this study and developed by the researcher to collect the necessary data:

\section{Tool I: A structured Interview Schedule}

To assess the demographic data, health behaviors knowledge and practices. It was developed by the investigators based on reviewing the relevant literatures.

This tool divided into three parts:

Part 1: Socio-demographic characteristics which included age, religion, residence, parents' educational level, mother's occupation.

Part 2: Health Knowledge regarding genital tract which included 14 questions: current vaginal discharge involving characteristics of discharge, color, odor and consistency; experiencing symptoms suggestive genital tract infection such as vaginal itching, redness, pain, and dysuria and taken prescribed medications. In addition to questions related to counseling providers and sources of information.

Part 3: Health practices among female students regarding prevention: which included 10 questions about the healthy practices related to perineal hygiene such as cleaning perineal area, methods of cleaning, direction of cleaning, dryness of perineal area, using antiseptic solution or not; toilet using hygiene as hand washing before and after using toilet; type of toilet, cleansing of toilet before using; receiving any guiding of menstrual hygiene, using health towels, frequency of changing health towels, type of underwear cloth; practice toward tight jeans wearing.

Scoring system for students' knowledge: The female students' knowledge was calculated for each item as follows: correct complete answer was scored (2 points), incomplete correct answer was scored (1 point), while wrong answer or don't know was scored (zero point). The total score for all questions related to knowledge was 48 point which represented $100 \%$ and categorized into two levels as followings: satisfactory $\geq 60 \%$ of the total score and unsatisfactory $<60 \%$ of the total score.

Scoring system for student health practice questionnaire: Each healthy practice was scored as one point and each unhealthy practice was scored as zero point. For the practice "yes" response scored as two and if response "no" scored as zero. The total score of practices was 20points, which represented $100 \%$. Final practice assessment score was as healthy practice $\geq 75 \%$ and unhealthy practice $<75 \%$.

Validity: The tools were prepared and reviewed to ascertain their content validity by five experts of obstetrics and gynecology in nursing and medicine. The recommended modifications were done accordingly, and then the tools were designed in its final format. The validity was $97.6 \%$. 
The reliability was assessed in the pilot study and it was estimated by alpha Cronbach's test for the tool and its result was $\mathrm{r}=0.76$.

\section{Method}

- An official permission was obtained from the dean of the Faculty of Nursing, Assiut University to the administrators of schools to carry out this study.

- Meetings with school managers to explain the objectives and contents of the program and the methods for applying the program were help to gain their cooperation and to allow the release of students to attend the program during minimal workload activities.

- Schools approvals were taken from district administration and directors of the three participating schools on September, 2015.

- Pilot study was carried out including 20 adolescent female students to assess the tool clarity, applicability, and time needed to fill each sheet. The participants of the pilot study were excluded from the main study sample.

- The actual field work started from beginning of October till the end of December 2016 for data collection.

\section{- Prevention guideline program included four phases:}

- Phase I (preparatory phase): the researchers interviewed students to explain the purpose of the study and reassure them that all data and results will be confidential. Structured interview schedule was fulfilled from each student. Two months were taken to collect data (pre-test data) from the three schools ( 3 hours for 3 days).

- Phase II (program planning): the program was designed based on the identified needs of adolescent female students.
- Phase III (program

implementation): the items of the prevention guideline program covered knowledge and practices of the students. Three sessions were used to apply the program. The students were classified into 6 groups each involved 20-21 students. The session of each group was scheduled based on availability of time and place which was commonly in the morning between 8.5am until 11.5am. Through three days/week, each session lasted4560 minutes. The $1^{\text {st }}$ session, included, pretest and teaching the students about knowledge regarding genital tract and its infection. The $2^{\text {nd }}$ session, included practices regarding personal hygiene and proper perinealcare. The $3^{\text {rd }}$ session: included practice regarding menstrual hygiene such as washing during menses, type of pads, frequency of change, perineal hygiene, underwear and methods of cleaning. At the end of each session the researchers ensured the females' adolescents students' instructions. The program was presented in clear and concise form and focused on the point of learning using different teaching methods, as illustrative lecture, group discussion, role playing, demonstration, and re demonstration were used. Also different audio visual materials were used as pamphlets; hand out, pictures, and posters to facilitate the teaching of each topic.

- Phase IV: evaluation of the program was done by comparing the change in female's students' knowledge and habitual practices after 9 weeks of implementation of the program using the same questionnaire (post-test). 


\section{Ethical considerations:}

All relevant ethical aspects were considered for ensuring female students' privacy and confidentiality of the collected data through; gaining formal consent for participation in the study, explaining the purpose of the study, right to refuse to continue participation.

\section{Statistical Analysis}

The collected data was analyzed using Statistical Package for Social Science (SPSS) version 20. Descriptive and inferential statistics were calculated for socio-demographics, respondents' healthy practices while chi-square was used for inferential statistics of studied parameters.

\section{Results}

A total of 124 female adolescents were recruited into the study that represented the categories of the secondary schools in Assiut City (public and technical). Their demographic data were presented in table (1). It was noticed that, students' age ranged from 15-18 years with a mean age of $16.7 \pm 1.2$ years. Most of the students $(88.7 \%)$ were Muslim and slightly more than half $(51.6 \%)$ of them from rural areas. Regarding, mother's education high percentage $(37 \%)$ of them was secondary level and the majority (70\%) of them were house wives. As the table illustrated, $75 \%$ of students reported that, the main source of consulting for advice was their mothers and high percentage of them (49\%) gained their knowledge about the reproductive system from their family members.

Comparison between pre-post intervention knowledge regarding personal health practices among adolescents in the study is displayed in table (2). It points to statistical significance differences between the two groups in the areas of knowledge related to types of sanitary pad used, frequency of changing sanitary pads per day and type of underwear clothes $(\mathrm{P} 0.005, \mathrm{P}$ 0.025 and $\mathrm{P} 0.00$, respectively). It was found that, most $(88.7 \%)$ of students used sanitary pads in spite of the cloth towels.
Also, the majority $(75.0 \%)$ of the study sample post intervention program changed their perineal pads on a napkin compared to $58.9 \%$ in pre intervention program and the percentage of them who changed pad less than 3 times was declined from two fifths $(40.0 \%)$ to less than one quarter $(24.2 \%)$. Regarding type of underwear clothes, the same table indicated that, post-intervention program only $(4.8 \%)$ of students still used non-cotton underwear. When the students were asked about suffering from symptoms of genital tract infection, it was found that, more than two fifth $(41.9 \%)$ of them had infection before program intervention compared to $36.6 \%$ at post-intervention.

Table (3) shows comparison between pre and post intervention regarding health practices among female adolescents in the study. The percentage of students' unhealthy practices of the perineal hygiene technique regarding to rinse from bottom to top declined after program intervention from $16.9 \%$ pre-intervention to only $2.4 \%$ and on other side, there was a highly statistical significant improvement in healthy practice related to rinse the pubic area from front to back and use hand while rinsing $(\mathrm{p}=0.001)$.The behavior of cleaning the genital tract was assessed in this study, before intervention program nearly two fifth $(37.9 \%)$ of students reported that they generally didn't clean genital tract while after program $78.2 \%$ of them frequently rinsed the genital tract with a statistically significant difference $(\mathrm{P}=0.006)$. As for, drying the pubic area after using the toilet, it was found that after program higher percentage $(60.5 \%)$ of students were drying pubic area with cotton cloth or tissue paper compared to $(36.3 \%)$ before intervention program which is an evidence of a positive impact of the program.

The same table, shows that, a half $(50.8 \%)$ of the students in pre-intervention reported that, they were cleaning the hands before using the toilet compared to (64.5\%) after the intervention program with statistically significant difference $(\mathrm{P}=0.029$. Furthermore, it was noticed that the studied 
students have done unhealthy habits as sharing underwear with others and using a public toilet seat were lower after the program $(39.5 \%$ and $4.0 \%)$ compared with $(41.9 \%$ and $8.9 \%)$ with no statistically significant difference.

Table (4) shows that, the percentages of students with satisfactory knowledge and adequate practice were significantly higher after the application of the intervention program $(\mathrm{P}=0.015$ and 0.024 , respectively).

Concerning the relationship between students' educational background and practice and their demographic characteristics, no statistically significant relation could be found between total knowledge score level and total practice score levels and demographic characteristics (table 5).

In order to assess the correlation between total score knowledge and practice (pre-and post-program) among studied students, table (6) reveals a positive correlation with a highly statistically significant correlation between knowledge and practice about genital tract infection in pre and post-intervention program $(\mathrm{P}<0.001)$.

\section{Discussion}

Prevention and treatment of STI based on accessible knowledge which is very important to avoid any complications for instance individuals who do not identify the symptoms may fail to seek outsupport $^{(12)}$.This study compare between students' practices regards to genital tract infection and the effect of prevention guidelines program on their behaviors based on different locality and education. The findings after applied of educational program concluded that more than half of participants had satisfactory health behavior and more than one-third had adequate healthy practice of hygienic care during reproductive infection and menstrual cycle.

Results of the present study indicated that, most of the students were Muslim and more than half of them from rural areas with a mean age of participant students were 16.7 \pm 1.2 years. Similarly, the same findings were reported by Gabster et al. ${ }^{(13)}$ $(16.9 \pm 1.1)$. This finding is consistent with Wagenlehner et al. study ${ }^{(14)}$ which considered this age as a risk factor to infection and it was mentioned that the highest prevalence of infection was found among 15-19-year-old females, whereas it significantly decreased after 25 years of age. Regarding to mother's education high percentage of them had secondary level and the majority of them were house wives. Similar findings were reached by Egyptian study ${ }^{(15)}$ which found that more than two thirds of them their mothers had intermediate education and the majority of their mothers' job was housewife.

Three-quarters of students in this study reported that the main source of consulting advice was their family "mothers" followed by more than fifteen percentage from internet while only $11 \%$ from Health care providers. However, almost fifty percent gained their knowledge about the reproductive system from their family members followed by mass media (more than $30 \%$ ) while school was almost thirty percent. This finding reflects the importance of the mother's role in advising her daughter. This observation may be explained according to our Egyptian tradition by the fact that young girls usually propound their emotional and psychological problems with their mothers because they mainly put their trust in them rather than anyone. In line with this finding, AbdElla $^{(16)}$ reported that the major source of information among adolescent girls.

Sumpter and Torondel ${ }^{(17)}$ confirmed that there was a clear association between unhealthy practices during menstruation and health problems such as urinary and reproductive tract infections (URTI). They contributed, this might be due to the fact that, during menstruation the cervix opens up and creates a pathway for bacteria to enter the uterus and pelvic cavity. In addition, during this period $\mathrm{PH}$ in the vagina is less acidic; there were a higher 
risk of infections. So, one of the main points in the present study's program was about personal health practices during menstruation. In this regard, the current results revealed an improvement of adolescents' knowledge regarding personal health practices during menstruation which displayed a statistical significance differences between pre and post intervention related to types of sanitary pad used, frequency of changing sanitary pads per day and type of underwear clothes. It was found that the majority of female students used sanitary pads in spite of the cloth towels. Also, three-quarters of the students increased the frequency changes of their perineal pads. These findings are in concordance with Egyptian study ${ }^{(18)}$ which was assessed impact of health education intervention on knowledge and practice about menstruation among female secondary school students and it was found that the majority of females' students had satisfactory menstrual hygiene practices after implementation the intervention.

However, the current findings related to change underwear daily and washing or boiling it was reflected less than one fifth for each. These findings incongruent with a study of Adika et al. ${ }^{(19)}$ which reported that the majority were using a regular washing of under wears, and regular changing of under wear. This incongruence may be related to the variety of items (6 items) due to using multiple choice questions to ask participants about hygienic care and also smaller size of our sample while Adika et al. ${ }^{(19)}$ used each item about hygienic care in the form of a separate question answered by "yes or no" so the participants' answers have only two choices.

This study also demonstrated that students reported significant improvements in the perienal hygiene practices, it was found that the students' unhealthy practices percentage of the perienal hygiene technique regarding rinsing from bottom to top was declined after program intervention to only $2.4 \%$ and on other side, there was a highly statistical significant improvement in healthy practice related to rinse the pubic area from front to back and use hand while rinsing $(\mathrm{p}=0.001)$. This finding is an evident that there is a positive impact of the program. Furthermore, it was noticed that the studied students who were practicing unhealthy habits as sharing underwear with others and using a public toilet were lower after the educational program but with no statistically significant difference. Similar findings were reached by Al-Kotb et al. ${ }^{(15)}$ who reported that the majority of students had unhealthy hygienic habitual practices regarding perianal area and care of under wear in the pre-test, whereas after implementation program, there was improvement in hygienic practice.

Instead of significant improvement in total knowledge score level and total practice score level about hygienic behaviors between pre and post-test it was changed from one-third to half for behaviors while from two-fifth to one-third in practice which considered between weak and fair. Similarly these findings were found in the study of knowledge, attitude and practice regarding prevention of common genital tract infection ${ }^{(20)}$.

In the present study, the percentages of the students who reported suffering from one or more symptoms of genital tract infection were declined after program intervention and on other side, there was improvement in seeking medical prescription related genital tract infection. These findings point to the positive effectiveness of the intervention program. The same results found in a study carried out by Al-Kotb et al. ${ }^{(15)}$ which found that the students' complaints from the symptoms of genitourinary tract infection before implementing program disappear after implementation.

The finding of students' knowledge and practice in relation to their mothers' education showed that more than one-third of students whom their mother had secondary education level reflected a satisfactory knowledge and adequate practice respectively. This might be 
justified as educated mothers usually educate and discuss freely issues related to reproductive health including menstruation with their daughters. Similarly finding reached by Oche, et al. ${ }^{(21)}$ in the study conducted in Sokoto, Nigeria about menstrual health: the unmet needs of adolescent girls' which interpreted by positive effect of educational background of mothers on their daughters' level of knowledge and practice. Likewise, the studies done in Nigeria, Lebanon, $\operatorname{India}^{(22,23,24)}$ found that there was a significant association between hygiene care and education level of mothers.

Regarding integrating knowledge into practice, the present study has demonstrated a statistically significant positive correlation between knowledge and practice, with satisfactory knowledge being associated with more healthy practice. This finding is quite expected and in congruence with Mohamed et al. ${ }^{(25)}$ who reported a statistical correlation between students' total knowledge score level and their total practice score level that demonstrated positive association between having satisfactory/unsatisfactory knowledge and healthy/unhealthy practices. Furthermore, Bobhate and Shrivastava ${ }^{(12)}$ mentioned that a significant positive correlation between having good/fair knowledge and good practice regarding menstrual health.

Finally, this intervention study has several important findings and insights for adolescent girls. However, it also has limitations. First, although all possible efforts were made to standardize the educational intervention, it is possible that environmental factors such as differences in the financial and physical abilities of students and their ability to disseminate study messages affected the outcome of the study. Second limitation of the present study was the findings were based on selfreported outcomes and may therefore differ from actual behavior. Adolescents may have over-reported their use of good menstrual hygiene in order to satisfy the interviewer.

\section{Conclusion}

Based on the results of the present study, it was concluded that students have deficient knowledge and healthy practice regarding genital tract infection. Implementation of the preventive guideline program based on assessment of their needs led to statistically significant improvements in the post-intervention knowledge and practice of students in the study. Therefore, the preventive guideline program was successful in achieving its goals.

\section{Recommendations}

In the light of the study findings, the following recommendations are suggested:

- More intense and continuous school education program is needed in the similar adolescents' populations.

- Appropriate educational strategies as simple illustration, brochures and booklets should be available for students to increase their awareness about the healthy practices regarding genital tract.

- School nurse must share in increasing awareness of adolescents and their families about the importance of using reproductive health services.

- Further researches are needed to test and verify the discrepancy of adolescents' health behaviors regarding genital tract infection. 
Table (1): Demographic characteristics of the studied students $(n=124)$

\begin{tabular}{|c|c|c|}
\hline Items & No. & $\%$ \\
\hline Age & \multirow{3}{*}{\multicolumn{2}{|c|}{$\begin{array}{c}15-18 \\
16.7 \pm 1.2\end{array}$}} \\
\hline Range & & \\
\hline Mean \pm SD & & \\
\hline Religion: & & \\
\hline Muslim & 110 & 88.7 \\
\hline Christian & 14 & 11.3 \\
\hline Residence & & \\
\hline Urban & 64 & 51.6 \\
\hline Rural & 60 & 48.4 \\
\hline Mother education & & \\
\hline Illiterate & 20 & 16.1 \\
\hline Read and write & 26 & 21.0 \\
\hline Secondary & 46 & 37.1 \\
\hline University & 32 & 25.8 \\
\hline Father education & & \\
\hline Illiterate & 8 & 6.5 \\
\hline Read and write & 26 & 21.0 \\
\hline Secondary & 42 & 33.9 \\
\hline University & 48 & 38.7 \\
\hline Mother occupation & & \\
\hline House wife & 87 & 70.2 \\
\hline Working & 37 & 29.8 \\
\hline Source of consulting & & \\
\hline Health care providers & 14 & 11.3 \\
\hline Mother & 93 & 75.0 \\
\hline Friends & 10 & 8.1 \\
\hline Network & 21 & 16.9 \\
\hline Mass media & 15 & 12.1 \\
\hline $\begin{array}{l}\text { Information resource } \\
\text { reproductive system: }\end{array}$ & & \\
\hline Family & 61 & 49.2 \\
\hline School & 36 & 29.0 \\
\hline Friends & 8 & 6.5 \\
\hline Mass media & 39 & 31.5 \\
\hline Health care providers & 16 & 12.9 \\
\hline
\end{tabular}


Table (2): Comparison between Pre and Post intervention knowledge regarding health practices among female adolescents $(n=124)$

\begin{tabular}{|c|c|c|c|c|c|}
\hline \multirow{2}{*}{ Items } & \multicolumn{2}{|c|}{ Pre } & \multicolumn{2}{|c|}{ Post } & \multirow{2}{*}{ P-value } \\
\hline & No. & $\%$ & No. & $\%$ & \\
\hline Personal health practices & & & & & \multirow{7}{*}{0.451} \\
\hline Use public water & 32 & 25.8 & 37 & 29.8 & \\
\hline Use pad daily & 19 & 15.3 & 19 & 15.3 & \\
\hline Change underwear daily & 21 & 16.9 & 21 & 16.9 & \\
\hline Use cotton underwear & 21 & 16.9 & 17 & 13.7 & \\
\hline Boil underwear & 19 & 15.3 & 18 & 14.5 & \\
\hline Cut nails often & 12 & 9.8 & 12 & 9.8 & \\
\hline Type of the used sanitary pad & & & & & \multirow{3}{*}{$0.005 * *$} \\
\hline 1. Use cloth towels & 31 & 25.0 & 14 & 11.3 & \\
\hline 2. Use of commercial sanitary napkins & 93 & 75.0 & 110 & 88.7 & \\
\hline Frequency of changing perineal pads/day & & & & & \multirow{4}{*}{$0.025^{*}$} \\
\hline 1. Less than 3 times & 50 & 40.3 & 30 & 24.2 & \\
\hline 2. On a napkin & 73 & 58.9 & 93 & 75.0 & \\
\hline 3. Change sanitary towels three times a day or more. & 1 & 0.8 & 1 & 0.8 & \\
\hline Underwear type: & & & & & \multirow{3}{*}{$0.000 * *$} \\
\hline 1.Cotton underwear & 93 & 75.0 & 118 & 85.2 & \\
\hline 2. Other material & 31 & 25.0 & 6 & 4.8 & \\
\hline Suffer from abnormal vaginal discharge & & & & & \multirow{3}{*}{0.192} \\
\hline Yes & 71 & 57.3 & 81 & 65.3 & \\
\hline No & 53 & 42.7 & 43 & 34.7 & \\
\hline If yes, type of discharge & & & & & \multirow{5}{*}{0.553} \\
\hline Colorless and odorless & 22 & 17.7 & 32 & 25.8 & \\
\hline Yellow with an unpleasant odor & 7 & 5.6 & 6 & 4.8 & \\
\hline White thick with the smell like yogurt. & 46 & 37.1 & 48 & 38.7 & \\
\hline Other & 0 & 0.0 & 1 & 0.8 & \\
\hline Suffer from one or more symptoms of genital tract infection & & & & & \multirow{3}{*}{0.362} \\
\hline & 52 & 41.9 & 45 & 36.3 & \\
\hline No & 72 & 58.1 & 79 & 63.7 & \\
\hline If yes, mention it(more than one item) & & & & & \multirow{6}{*}{0.331} \\
\hline Itching & 22 & 42.3 & 24 & 53.3 & \\
\hline Redness & 2 & 3.8 & 5 & 11.1 & \\
\hline Burning sensation in the pubic / vagina & 5 & 9.6 & 5 & 11.1 & \\
\hline Copious discharge & 6 & 11.5 & 4 & 8.8 & \\
\hline All of the above & 23 & 44.2 & 19 & 42.2 & \\
\hline Did you receive any management for the vaginal secretions? & & & & & \multirow{3}{*}{1.000} \\
\hline Yes & 20 & 16.1 & 20 & 16.1 & \\
\hline No & 104 & 83.9 & 104 & 83.9 & \\
\hline $\begin{array}{l}\text { If yes, type of the management } \\
\text { Medical prescription }\end{array}$ & 6 & 30.0 & 7 & 35.0 & \multirow{4}{*}{0.548} \\
\hline Bathing & 13 & 65.0 & 12 & 60.0 & \\
\hline Rest & 0 & 0.0 & 1 & 5.0 & \\
\hline Other & 1 & 5.0 & 0 & 0.0 & \\
\hline
\end{tabular}


Table (3): Comparison between Pre and Post intervention regarding health practices among female adolescents $(n=124)$

\begin{tabular}{|c|c|c|c|c|c|}
\hline \multirow{2}{*}{ Items } & \multicolumn{2}{|c|}{ Pre } & \multicolumn{2}{|c|}{ Post } & \multirow{2}{*}{$\begin{array}{c}P . \\
\text { value }\end{array}$} \\
\hline & No. & $\%$ & No. & $\%$ & \\
\hline \multicolumn{6}{|l|}{ Toilet type } \\
\hline Seat toilet & 68 & 54.8 & 90 & 72.6 & \multirow{3}{*}{$0.013^{*}$} \\
\hline Pot toilet & 54 & 43.5 & 32 & 25.8 & \\
\hline Both & 2 & 1.6 & 2 & 1.6 & \\
\hline \multicolumn{6}{|l|}{ Received guidance about the menstrual cycle hygiene } \\
\hline Yes & 93 & 75.0 & 113 & 91.1 & \multirow{2}{*}{$0.001 * *$} \\
\hline No & 31 & 25.0 & 11 & 8.9 & \\
\hline \multicolumn{6}{|l|}{$\begin{array}{l}\text { If yes, hygienic care used during menstruation (more } \\
\text { than } 1 \text { item) }\end{array}$} \\
\hline 1.Warm bath & 39 & 41.9 & 57 & 51.1 & \multirow{4}{*}{0.678} \\
\hline 2.Clean and wash the perineum & 13 & 14.0 & 21 & 18.6 & \\
\hline 3.Taking a shower during menstruation & 51 & 54.8 & 62 & 54.9 & \\
\hline 4. Other & 3 & 3.2 & 2 & 1.7 & \\
\hline \multicolumn{6}{|l|}{ Which of the following practices do? } \\
\hline None & 39 & 31.5 & 55 & 44.4 & \multirow{6}{*}{0.131} \\
\hline Wearing tight clothing (jeans) for a long time & 52 & 41.9 & 49 & 39.5 & \\
\hline Sharing underwear with others (sister, mother) & 11 & 8.9 & 5 & 4.0 & \\
\hline Use a public toilet seat & 15 & 12.1 & 13 & 10.5 & \\
\hline Wearing tight (jeans) \&Use a public toilet seat. & 5 & 4.0 & 2 & 1.6 & \\
\hline Sharing underwear with others and use a public toilet seat & 2 & 1.6 & 0 & 0.0 & \\
\hline \multicolumn{6}{|l|}{ The perineal hygiene technique: } \\
\hline Rinse from bottom to top & 21 & 16.9 & 3 & 2.4 & \multirow{4}{*}{$0.001 *$} \\
\hline Rinse the pubic area from front to back. & 64 & 51.6 & 68 & 54.8 & \\
\hline Use hand while rinsing & 24 & 19.4 & 34 & 27.4 & \\
\hline Use soap and running water & 15 & 12.1 & 19 & 15.3 & \\
\hline \multicolumn{6}{|l|}{ The behavior of cleaning the genital tract: } \\
\hline 1.Do not care & 47 & 37.9 & 27 & 21.8 & \multirow{2}{*}{$0.006^{* *}$} \\
\hline 2. Rinse the pubic frequently & 77 & 62.1 & 97 & 78.2 & \\
\hline \multicolumn{6}{|l|}{ Drying the pubic area after using the toilet } \\
\hline Do not dry up. & 79 & 63.7 & 49 & 39.5 & \multirow{2}{*}{$0.000 * *$} \\
\hline Drying pubic area with cotton cloth or tissue paper. & 45 & 36.3 & 75 & 60.5 & \\
\hline \multicolumn{6}{|l|}{ Clean hands after using the toilet } \\
\hline No & 12 & 9.7 & 18 & 14.5 & \multirow{2}{*}{0.243} \\
\hline Yes & 112 & 90.3 & 106 & 85.5 & \\
\hline \multicolumn{6}{|l|}{ Clean hands before using the toilet } \\
\hline No & 61 & 49.2 & 44 & 35.5 & \multirow[t]{2}{*}{$0.029 *$} \\
\hline Yes & 63 & 50.8 & 80 & 64.5 & \\
\hline
\end{tabular}

*Statistically significant difference $(p<0.05)$

**Highly statistical significant difference $(p<0.01)$ 
Table (4): Comparison between Pre-Post intervention regarding total health knowledge and practice scores among students $(n=124)$

\begin{tabular}{|c|c|c|c|c|c|}
\hline \multirow{2}{*}{ Items } & \multicolumn{2}{|c|}{ Pre } & \multicolumn{2}{|c|}{ Post } & \multirow{2}{*}{ P-value } \\
\hline & No. & $\%$ & No. & $\%$ & \\
\hline $\begin{array}{l}\text { Total knowledge } \\
\text { Satisfactory } \\
\text { Unsatisfactory }\end{array}$ & $\begin{array}{l}44 \\
80\end{array}$ & $\begin{array}{l}35.5 \\
64.5\end{array}$ & $\begin{array}{l}63 \\
61\end{array}$ & $\begin{array}{l}50.8 \\
49.2\end{array}$ & $0.015^{*}$ \\
\hline $\begin{array}{l}\text { Total Practices } \\
\text { Adequate } \\
\text { Inadequate }\end{array}$ & $\begin{array}{l}27 \\
97\end{array}$ & $\begin{array}{l}21.8 \\
78.2\end{array}$ & $\begin{array}{l}43 \\
81\end{array}$ & $\begin{array}{l}34.7 \\
65.3\end{array}$ & $0.024 *$ \\
\hline
\end{tabular}

* Statistically significant difference $(p<0.05)$

** Statistically significant difference $(p<0.01)$

Table (5): Relationship between students' knowledge and practice regarding genital tract infection and their demographic characteristics $(n=124)$

\begin{tabular}{|c|c|c|c|c|c|c|c|c|c|c|}
\hline & \multicolumn{4}{|c|}{ Health Knowledge } & \multirow{3}{*}{$\begin{array}{c}P . \\
\text { value }\end{array}$} & \multicolumn{4}{|c|}{ Healthy Practice } & \multirow{3}{*}{$\begin{array}{c}P . \\
\text { value }\end{array}$} \\
\hline & \multicolumn{2}{|c|}{ Satisfactory } & \multicolumn{2}{|c|}{ Unsatisfactory } & & \multicolumn{2}{|c|}{ Adequate } & \multicolumn{2}{|c|}{ Inadequate } & \\
\hline & No & $\%$ & No & $\%$ & & No & $\%$ & No & $\%$ & \\
\hline Total & 27 & 100 & 97 & 100 & & 44 & 100 & 80 & 100 & \\
\hline Age & \multicolumn{2}{|c|}{$16.9 \pm 1.3$} & \multicolumn{2}{|c|}{$16.7 \pm 1.3$} & 0.677 & \multicolumn{2}{|c|}{$16.9 \pm 1.3$} & \multicolumn{2}{|c|}{$16.7 \pm 1.3$} & 0.277 \\
\hline \multicolumn{11}{|l|}{ Religion } \\
\hline Muslim & 26 & 96.3 & 84 & 86.6 & \multirow{2}{*}{0.159} & 40 & 90.9 & 70 & 87.5 & \multirow{2}{*}{0.566} \\
\hline Christian & 1 & 3.7 & 13 & 13.4 & & 4 & 9.1 & 10 & 12.5 & \\
\hline \multicolumn{10}{|l|}{ Residence } & \multirow{3}{*}{0.521} \\
\hline Urban & 14 & 51.9 & 50 & 51.5 & \multirow{2}{*}{0.978} & 21 & 47.7 & 43 & 53.8 & \\
\hline Rural & 13 & 48.1 & 47 & 48.5 & & 23 & 52.3 & 37 & 46.3 & \\
\hline Mother education & & & & & \multirow{5}{*}{0.452} & & & & & \multirow{5}{*}{0.515} \\
\hline Illiterate & 6 & 22.2 & 14 & 14.4 & & 8 & 18.2 & 12 & 15.0 & \\
\hline Read and write & 4 & 14.8 & 22 & 22.7 & & 11 & 25.0 & 15 & 18.8 & \\
\hline Secondary & 12 & 44.4 & 34 & 35.1 & & 17 & 38.6 & 29 & 36.3 & \\
\hline University & 5 & 18.5 & 27 & 27.8 & & 8 & 18.2 & 24 & 30.0 & \\
\hline $\begin{array}{l}\text { Father education } \\
\text { Illiterate }\end{array}$ & 4 & 14.8 & 4 & 4.1 & \multirow{4}{*}{$0.031 *$} & 4 & 9.1 & 4 & 5.0 & \multirow{4}{*}{$0.043 *$} \\
\hline Read and write & 3 & 11.1 & 23 & 23.7 & & 8 & 18.2 & 18 & 22.5 & \\
\hline Secondary & 13 & 48.1 & 29 & 29.9 & & 21 & 47.7 & 21 & 26.3 & \\
\hline University & 7 & 25.9 & 41 & 42.3 & & 11 & 25.0 & 37 & 46.3 & \\
\hline $\begin{array}{l}\text { Mother occupation } \\
\text { House wife }\end{array}$ & 19 & 70.4 & 68 & 70.1 & 0.979 & 33 & 75.0 & 54 & 67.5 & \multirow[b]{2}{*}{0.382} \\
\hline Working & 8 & 29.6 & 29 & 29.9 & 0.979 & 11 & 25.0 & 26 & 32.5 & \\
\hline
\end{tabular}

Table (6): Correlation between total score knowledge and practice among students at pre-and post-intervention program $(n=124)$

\begin{tabular}{|l|c|c|}
\hline Items & Pre-program & Post-program \\
\hline $\begin{array}{l}\text {-Knowledge } \\
\text {-Practice }\end{array}$ & $\mathrm{r}=0.897$ & $\mathrm{r}=0.771$ \\
\hline $\mathrm{P}-$ value & $\mathrm{P}<0.001^{* *}$ & $\mathrm{P}<0.001^{* *}$ \\
\hline
\end{tabular}




\section{References}

1. Prusty, R, Unisa, S.: Reproductive Tract Infections and Treatment Seeking Behavior among Married Adolescent Women in India, Paper to be presented at the Population Association of America.(2012), Annual Meeting Program, San Francisco.

2. Kučinskienė V, Šutaitė I, Valiukevičienė $S$, Milašauskienè $Z$ and Domeika M: Prevalence and risk factors of genital Chlamydia trachomatis infection. Medicina (Kaunas). 2006; 42(10). Available at: http://medicina.kmu.lt.

3. Niekerk, V, Barnard, E, and Justhinus, G: Women College Students Health Aspects, College Student Journal,

Project Innovation (Alabama). 2011; 45(3).

4. Omidvar, S Begum, K: Factors Influencing Hygienic Practices during MensesAmongst Girls from South India. A Cross Sectional Study. International Journal of Collaborative Research on Internal Medicine \& Public Health. 2010;2 (12): 411-423. [Online], Available at: http://www.iomcworld.com/ijcrimph/files/v0 2-n12-01.pdf.

5. Lowdermilk, D, Leonard, Perry, T: Maternity Nursing, $7^{\text {th }}$ ed., Mosby Co, Philadelphia, 2006.p. 111.

6. Salhan, S, (2011): Textbook of Gynecology, Jaypee Brothers Medical Publishers, New Delhi, $1^{\text {st }}$ ed. 2011. p.241.

7. Katz, M: Sexually Transmitted Diseases \&Reproductive Infections, Wild Iris Medical Education, Inc. 2009, (Accessed July, 2012). Available at: http://www.nursingceu.com/courses/269/inde x nceu.html.

8. El Nouman A: Female youth health promotion model in primary health care: acommunitybased study in rural Upper Egypt. East Mediterr Health J.2009.

9. Van Eijk A:Menstrual hygiene management among adolescent girls in India: a systematic review and meta-analysis. BMJ 2016; 6(3): e010290.
10. Hanafy S, ELsharkawy O, Abdelbaqy M, Tewfik M: Minding the Gap in Alexandria Talking to Girls in Schools about Reproductive Health, Population Reference Bureau2012. Available at: http://www.prb.org.

11. Bhuiya I, Rob U, Khan ME, Al Kabir A: Improving Adolescent Reproductive Health in Bangladesh, Population Council, 2004.

12. Bobhate P, Shrivastava: Across Sectional Study of Knowledge \& Practices about Reproductive Health among Female Adolescents In urban Mumbai. Journal of Family \& Reproductive Health 2011; 5(4): 123.

13. Gabster A, Mohammed D, Arteaga G, Castillero O, Mojica N, Dyamond J: Correlates of Sexually Transmitted Infections among Adolescents Attending Public HighSchools, Panama. PLoS ONE 2016;11(9): e0163391. doi:10.1371/journal.pone.0163391

14. Wagenlehner F, Weidner W, Naber K: Chlamydial infections in urology. World $\mathrm{J}$ Urol. 2006;24(1):4-12.

15. Al-Kotb H,Elbahnasawy H, El Nagar S Ghabyen N: Prevention for Genitourinary Tract Infection among Female Adolescents Students. Journal of Nursing and Health Science 2016 Volume 5, Issue 4 Ver. III: 1218. Available at: http://www.iosrjournals.org).

16. Abd-Ella N: Premenarcheal Heath Education Needs among Early Adolescent Girls, Thesis of Doctor Degree, Faculty of Nursing, Alexandria University 2010:89.

17. Sumpter C, Torondel B: A systematic review of the health and social effectsof menstrual hygiene management. PLoS ONE 2013;8:e62004.

18. Allah E, Elsabagh E:Impact of health education intervention on knowledge and practice about menstruation among female secondary school students in Zagazig city. The Journal of American Science. 2011; 7: 737-747. 
19. Adika V, Ayinde M Jack-Ide I: Self-care practices of menstrual hygiene among adolescents school going girls in Amassoma Community, Bayelsa State. International Journal of Nursing and Midwifery. 2013; Vol. 5(5): 99-105, DOI: 10.5897/IJNM2013.0102. Available at: http://www.academicjournals.org/IJNM

20. Farokhzadian Ja, Mangolian S, Mozaffari N: Survey Of Women's Knowledge, Attitude And Practice Regarding Prevention Of Common Genital Tract Infection. Procedia Social and Behavioral Sciences. 2014; (136): $381-384$.

21. Oche O, Umar S, Gana J, Ango T: Menstrual health: the unmet needs of adolescent girls' in Sokoto, Nigeria. Sci Res Essays. 2012;7(3):410-8.

22. Ravindran S: Menstrual hygiene practices and Reproductive morbidity-A Community
Based Survey in Rural Thiruvananthapuram, Kerala. Sree Chitra Tirunal. 2008. p. 12.

23. Santina T, Wehbe N, Ziade FM, Nehme M: Assessment of beliefs and practices relating to menstrual hygiene of adolescent girls in Lebanon. Int $\mathbf{J}$ Health Sci Res. 2013;3(12):75-88

24. Patavegar BN, Kapilashrami MC, Rasheed N, Pathak R: Menstrual hygiene among adolescent school girls: an in-depth crosssectional study in an urban community. Int $\mathbf{J}$ Health Sci Res. 2014;4(11):15-21.

25. Mohamed HB, Al-Beih AA, Dawah AA, Abd-ElAal EM: Health Practices among Female University Students Regarding Prevention of Reproductive Tract Infections. Thesis, Public Health Nursing. 2013; Benha University. 